\title{
Andrzej Stawicki
}

Uniwersytet Marii Curie-Skłodowskiej

\section{Strategie adaptacji polskich uniwersytetów do współczesnej rzeczywistości społecznej}

STRESZCZENIE W artykule autor przedstawia tendencje zachodzące w procesie zmiany modelu zarządzania w szkolnictwie wyższym. $\mathrm{Na}$ podstawie dokumentów strategicznych polskich uniwersytetów oraz literatury przedmiotu podejmuje próbę opisania procesu przemian dokonujących się w tym obszarze. Zachodzące zmiany postrzega z punktu widzenia procesualnego ujęcia organizacji, bazującego w dużym stopniu na teorii systemów społecznych $\mathrm{Ni}$ klasa Luhmanna. Z tej perspektywy strategie rozwoju uniwersytetów interpretowane są jako forma adaptacji do zmieniającego się kontekstu. Autor posługuje się również teorią pola społecznego Pierre'a Bourdieu w celu opisania złożonych relacji dominacji i podporządkowania, jakim ulegają wraz ze zmianą kontekstu polskie uniwersytety, a także konsekwencji zmian dla pola nauki. W celu wyeksponowania centro-peryferyjnych relacji, jakie zachodzą w powstającym nowym obszarze szkolnictwa wyższego, autor wykorzystuje koncepcję systemu-świata Immanuela Wallersteina.

\section{SŁOWA KLUCZOWE}

PRZEMIANY W OBSZARZE SZKOLNICTWA

WYŻSZEGO, SOCJOLOGIA ORGANIZACJI, ANALIZA PÓL SPOŁECZNYCH, RELACJE DOMINACJI W POLU AKADEMICKIM 


\section{Ramy teoretyczne analizy zmian w uniwersytetach}

W analizie aktualnej sytuacji współczesnych uniwersytetów użyteczna jest teoria systemów społecznych Niklasa Luhmana, a także teoria pól społecznych Pierre’a Bourdieu. Autor koncepcji autopojetycznych systemów społecznych zakładał, że systemy społeczne są systemami komunikacji. Wszystko, co jest komunikacją - i tylko to - składa się na ogólnie rozumiany system społeczny. Koncepcja autopojezy zakłada natomiast, że systemy społeczne mają zdolność wytwarzania samooodniesień oraz różnicowania tych odniesień w stosunkach z własnym środowiskiem (Luhmann 2008). Zakłada ona, że systemy społeczne same wytwarzają elementy, z których się składają, dokonują samoobserwacji, która umożliwia im odróżnienie samych siebie od otoczenia, w którym funkcjonują, oraz wytworzenie różnicy, na podstawie której są od niego odróżniane również przez innych. Jak pisze Luhmann:

Systemy nie występują jedynie kontyngentnie i nie są tylko adaptacyjne, lecz strukturalnie orientują się na swe środowisko, bez środowiska nie mogłyby istnieć. Konstytuują się i utrzymują poprzez wytwarzanie różnicy pomiędzy sobą a środowiskiem (...). W tym sensie utrzymanie granicy jest utrzymaniem systemu (Luhmann 2008: 23).

Tym, co odróżnia dany system od otoczenia, jest jego funkcja, a warunkiem przetrwania w dynamicznym kontekście społecznym jest umiejętność odróżnienia się, wytworzenia i podtrzymania tożsamości systemu, polegająca na zachowaniu unikalnych dla niego funkcji.

Przyjmując punkt widzenia Luhmana, uniwersytet należy traktować jako podsystem w szerszym systemie społecznym, pozostający w ścisłej relacji ze swoim szeroko rozumianym otoczeniem (środowiskiem). Podejście autora jest określane jako radykalnie konstruktywistyczne, co oznacza, że tożsamość uniwersytetu (oraz jej konsekwencje w postaci struktur i działania) jest wprawdzie definiowana przez sam uniwersytet, jednak definicja ta w dużym stopniu zależy również od „sygnałów z zewnątrz”. Z tego wynika, że systemy społeczne mają charakter „półotwarty”. Posiadają zdolność wytwarzania samoodniesień i różnicowania ich w stosunkach z własnym środowiskiem (Luhmann 2008). Są operacyjnie zamknięte, jednak pozostają w relacji z otoczeniem. Ulegają jego wpływom i modyfikują swoją wewnętrzną złożoność w celu adaptacji do środowiska.

Podejście Luhmana znalazło zwolenników w dziedzinie socjologii organizacji. Perspektywa ta znacząco wpłynęła na zmianę zainteresowań badawczych ze statyki oraz zainteresowania mechanizmami stabilizacji organizacji w kierunku analizy procesu permanentnej zmiany oraz relacji z otoczeniem. Organizacje przestano postrzegać jako statyczne obiekty, natomiast zaczęto ujmować je jako dynamiczne procesy (Hatch 2002). Koncepcje autopojezy i autoreferencyjności miały znaczący wpływ na ukształtowanie się sposobu myślenia o organizacjach jako o systemach uczących się. W tej teorii należy szukać źródeł terminów „uczenie się organizacji” oraz „zwrotność myślenia/uczenia się organizacyjnego” (double loop learning). Zwrotność ta polega na tym, że nie tylko dokonuje się obserwacja otoczenia, ale również obserwacja własnego sposobu myślenia i mechanizmów uczenia się organizacji (Hatch 2002). Systemy refleksyjnie orientują się na swoje środowisko i w odniesieniu do własnej tożsamości (autodefinicji) interpretują to, co zostaje włączone do obszaru ich oddziaływania, a co pozostaje poza nim. W odniesieniu do obecnych tendencji w postrzeganiu uniwersytetu jako instytucji odpowiedzialnej i zaangażowanej w proces zmian swojego otoczenia społecznego mechanizmy komunikacji z nim i uczenia się wydają się szczególnie 
istotne i godne zainteresowania badawczego, gdyż obecnie wdrażane w tym celu instrumenty często są krytykowane i uznawane za nieskuteczne. W przekonaniu autora potrzebna jest refleksja nad funkcjonującymi mechanizmami uczenia się organizacyjnego i dostosowania ich do specyfiki modelu organizacyjnego polskich uniwersytetów.

Teoria Pierre'a Bourdieu natomiast pozwala na lepsze zrozumienie tego, na czym polega opisywana przez Luhmanna relacja między systemem a jego środowiskiem. Jeżeli założymy, że na owe środowisko składają się również inne systemy, zgodnie z podejściem Bourdieu, relacje między nimi należy rozpatrywać jako asymetryczne/hierarchiczne. Jak pisze autor: „rozpoczynając analizę każdego pola społecznego, należy rozpoczynać od ustalenia jego pozycji w stosunku do pola władzy" (Bourdieu, Wacquant 2006: 656). Luhmann władzę ujmował ogólnie - jako jedno z mediów komunikacji międzysystemowej. Bourdieu natomiast daje bliższe spojrzenie na ten problem, odwołując się do dyskursu jako środka jej sprawowania i utrzymywania przez elity symbolicznie stosujące strategię naturalizacji pewnego, zgodnego z ich interesem, obrazu rzeczywistości i strategię jej wartościowania (Bourdieu, Wacquant 2006). Dzięki temu podejściu można lepiej opisać i zrozumieć pewne strategie narzucania misji uniwersytetów przez silniejszych aktorów zewnętrznych.

Podejście Bourdieu dostarcza narzędzi teoretycznych, pozwalających krytycznie spojrzeć również na wdrażane mechanizmy zarządzania w polu akademickim, służące zwiększaniu wydajności i efektywności procesów w nim zachodzących. W swojej teorii pola symbolicznego autor wskazuje, że każde pole posiada własną logikę, własne stawki i reguły gry. Nadrzędnym elementem analizy pól jest identyfikacja wewnętrznej logiki nimi rządzącej oraz rodzaju kapitału, o który toczy się gra w danym polu. Jak pisze Bourdieu:

(...) w społeczeństwach silnie zróżnicowanych wszechświat społeczny składa się z szeregu względnie autonomicznych mikrokosmosów, przestrzeni obiektywnych relacji, będących terenem działania specyficznej logiki i przymusu, niedających się sprowadzić do tych, które rządzą innymi polami (Bourdieu, Wacquant 2006: 652).

Bourdieu wskazuje, że relacje wewnątrz pola mają charakter walki (lub gry) o uprzywilejowaną pozycję w dostępie do kapitału, o który toczy się gra, a pozycja ta determinuje zwrotnie władzę w danym polu, pozwala posiadaczowi wywierać wpływ i kształtować reguły gry w danym polu (Bourdieu, Wacquant 2006). Mechanizm ten w polu nauki stanowi czynnik jej rozwoju i gwarancję jakości. Zapożyczanie mechanizmów sprawdzonych w polu gospodarki - różniącym się zasadniczo pod względem wewnętrznej logiki od pola nauki - jest w moim przekonaniu ingerencją powodującą niekorzystne zmiany dotyczące jakości realizowanych badań, w szczególności podstawowych.

Teoria Immanuela Wallersteina systemu-świata pozwala w analizie uchwycić szerszy, makrospołeczny kontekst funkcjonowania polskich uniwersytetów. Jego ujęcie koncentruje się na powstawaniu i utrwalaniu relacji dominacji i podporządkowania w kategoriach ekonomicznych, jednak mechanizm ten wydaje się możliwy do zastosowania również podczas próby konceptualizacji obecnej sytuacji polskich uniwersytetów, które włączone do Europejskiego Obszaru Szkolnictwa Wyższego i Europejskiej Przestrzeni Badawczej, poza szansą rozwoju i umiędzynarodowienia swojej działalności, narażone zostają na efekt osłabienia i peryferyzacji przez ośrodki centralne (Wallerstein 1976).

Podsumowując tę część rozważań, należy wskazać, że analiza strategii adaptacyjnych polskich uniwersytetów musi uwzględniać szeroki zakres przemian. Krytyczne spojrzenie 
na podejmowane obecnie i planowane działania jest możliwe dzięki osadzeniu ich w międzynarodowym kontekście, charakteryzującym się dużym stopniem hierarchiczności i nierówności w zakresie możliwości stanowienia własnych ścieżek rozwoju. Zarówno ujęcia Luhmanna, Bourdieu, jak i Wallersteina umożliwiają spojrzenie na wyłaniającą się nową przestrzeń zależności i powiązań, która łączyć się będzie z powstawaniem nowych obszarów wielowymiarowej dominacji i podporządkowania w polu akademickim.

\section{Nowy kontekst funkcjonowania uniwersytetów}

Analizując zmiany w zakresie zarządzania uniwersytetami, nie sposób nie dostrzec, że wynikają one ze zmieniającego się postrzegania ich zasadniczych funkcji oraz wzrostu oczekiwań wobec nich kierowanych. Uniwersytety w ostatnim czasie stają się kluczowym elementem realizacji projektu tzw. Gospodarki Opartej na Wiedzy (GOW), która stanowi pewien typ modelowy oraz cel modernizacji gospodarki. Należy do niego dążyć, aby zapewnić sobie konkurencyjność w globalnym systemie rynkowym. W wyniku upowszechnienia tego paradygmatu zwiększa się również nacisk na uniwersytety, które są źródłem wiedzy i motorem rozwoju tego modelu gospodarki (Denek 2010).

Marek Kwiek w swojej książce dotyczącej procesu transformacji uniwersytetów wskazuje, że analiza przemian ich funkcjonowania powinna odbywać się przede wszystkim z punktu widzenia napięcia między ich tradycyjną funkcją a istniejącymi w społeczeństwie interesami (Kwiek 2010a). Poza obiektywnymi czynnikami strukturującymi obecnie pole akademickie (jak np. demografia) bardzo duże znaczenia mają czynniki o charakterze intencjonalnym. Należy zauważyć, że przyjęcie za wzorzec modelu gospodarki opartej na wiedzy jest efektem arbitralnej decyzji, podjętej przez globalne instytucje, będące pod silnym wpływem Stanów Zjednoczonych, takie jak OECD, Bank Światowy, Międzynarodowy Fundusz Walutowy, „mające moc promowania pewnych idei nie tylko poprzez środki symboliczne, ale również presję instytucjonalną" (Zarycki 2014: 22). Upowszechnienie w Europie rozwiązań sprawdzonych w USA, gdzie stopień urynkowienia uniwersytetów jest najwyższy i dość silnie zakorzeniony kulturowo (Clark 1983), nie jest zatem rezultatem „ewolucyjnego" przejścia do nowego modelu, ale raczej realizacją pewnego projektu, w którym rola edukacji i nauki ulega daleko idącej instrumentalizacji.

W paradygmacie modernizacji GOW uczelnie wyższe zyskują bardzo duże znaczenie, gdyż są postrzegane jako miejsce kluczowe w powstawaniu wiedzy i innowacji, będących jej kluczowymi zasobami. Tradycyjne czynniki rozwoju, takie jak praca i zasoby materialne, ustępują miejsca wiedzy, która staje się kapitałem XXI wieku (Denek 2010). Sytuacja taka jednocześnie stawia uczelnie na pozycji w dużym stopniu podporządkowanej celom gospodarczym. Skutkuje to coraz większą ingerencją zewnętrzną w logikę funkcjonowania pola naukowego, wyrażającą się narzucaniem zasad zarządzania i stymulowania efektywności poprzez instrumenty charakterystyczne dla pola ekonomicznego oraz w definiowaniu przez aktorów spoza murów uczelni celów, jakie ma ona realizować. W coraz większym stopniu aktorzy zewnętrzni, jak OECD - a w przypadku Polski Komisja Europejska wyznaczają trendy w dziedzinie badań naukowych (poprzez określanie priorytetowych obszarów), jak i kształcenia - poprzez wskazywanie kluczowych z punktu widzenia gospodarki kwalifikacji i kompetencji. Jako przykład może posłużyć ostatni dokument wydany przez OECD, dotyczący kluczowych dla gospodarki kompetencji absolwentów (OECD 2014).

Jak wcześniej wskazano, tzw. dyskurs neoliberalny, którego autorami są elity ekonomiczne i polityczne (wskazuje się również szczególną rolę będących w związku z nimi 
intelektualistów), naturalizuje pewne sprawdzone głównie w USA rozwiązania, nadając im cechy pewności i naukowości. Według Pierre’a Bourdieu dyskurs ten jest dziś bardzo silny, gdyż wiąże się z interesem obecnych elit ekonomicznych, a siła ta wyraża się we wpływie na różne sfery życia społecznego (Bourdieu, Wacquant 2007). W szkolnictwie wyższym w szczególności widoczne są tego efekty, gdyż coraz częściej w celu wprowadzenia pożądanych zmian używa się języka odwołującego się do takich kategorii, jak: przedsiębiorczość, wydajność, jakość produktu, potrzeby interesariuszy, konkurencyjność itd. Kwiek (2010: 72) nazywa to zjawisko „ekonomizacją i dezakademizacją” dyskursu dotyczącego nauki. Dyskurs ten przekształca cele funkcjonowania uniwersytetów i podporządkowuje je w coraz większym stopniu celom gospodarczym. W zakresie tworzenia wiedzy akcentuje się rolę badań o wysokim potencjale innowacyjnym, w zakresie kształcenia - jego powiązanie z potrzebami rynku pracy.

W opinii wielu autorów paradoksalną sytuacją jest jednoczesne podkreślanie szczególnego znaczenia uniwersytetów dla rozwoju przy jednoczesnym ograniczaniu środków publicznych przeznaczanych na ich rozwój. Przyczyną takiej sytuacji jest zdaniem Kwieka globalna przemiana sektora publicznego, w tym funkcji państwa opiekuńczego, od którego zależy ewolucja szkolnictwa wyższego. W sytuacji jego uszczuplonych dochodów pojawia się konieczność rywalizacji międzysektorowej o zasoby i - jak wskazuje autor - w najbliższym czasie konieczne będzie renegocjowanie jego podstawowych funkcji. Wśród czynników determinujących przyszły kształt państwa dobrobytu, a tym samym kształt uniwersytetów, autor wymienia kwestie gospodarcze, demograficzne, a także postępujący proces globalizacji (Kwiek 2010a). W związku z tym coraz bardziej promowana jest koncepcja uniwersytetu przedsiębiorczego, zarządzanego w sposób profesjonalny (poprzez wdrożenie systemu planowania strategicznego oraz instrumentów kontroli jakości) oraz uniezależniającego się w coraz większym stopniu od finansowania z budżetu państwa. Jak pisze autor, w przyszłości możemy spodziewać się rosnącej powszechności tak zorganizowanych instytucji szkolnictwa wyższego (Kwiek 2010a). W obliczu kurczenia się środków publicznych konieczna będzie selekcja, wybór priorytetowych kierunków rozwoju nauki i z pewnością większe przywileje zyskają dziedziny o wysokim potencjale innowacyjnym i komercyjnym, kosztem badań podstawowych, w szczególności w dyscyplinach, których działalność nie wpływa natychmiastowo na rozwój gospodarki, a ich oddziaływanie jest trudno uchwytne podczas pomiaru bazującego na wskaźnikach ilościowych.

Innym czynnikiem wpływającym na kontekst funkcjonowania uniwersytetów jest rosnące znaczenie w tworzeniu nowych idei i rozwiązań instytucji spoza akademii. Jak pisze Michael D. Kennedy (2014: 78), „szczególnie od roku 1990 rośnie w tym zakresie rola różnego typu think tanków, organizacji pozarządowych, ośrodków badawczych związanych z instytucjami państwowymi oraz prywatnymi korporacjami”. Jako przykład instytucji mającej silny wpływ oraz ambicje narzucania swoich projektów poprzez tworzenie różnego typu ekspertyz autor wskazuje Bank Światowy (Kennedy 2014). Działania takich globalnych aktorów wpływają znacząco na kształt narodowych polityk publicznych.

W obrębie Unii Europejskiej czynnikiem determinującym funkcjonowanie uniwersytetów jest proces boloński, którego celem jest stworzenie Europejskiej Przestrzeni Badawczej oraz Europejskiego Obszaru Szkolnictwa Wyższego. Stanowią one element szerszego projektu „tworzenia w Europie najbardziej dynamicznej i konkurencyjnej w skali globalnej gospodarki opartej na wiedzy, zapewniającej zrównoważony rozwój, charakteryzujący się poprawą warunków zatrudnienia i harmonią społeczną" (Kraśniewski 2007: 63). Jest to 
projekt mający odpowiadać wyzwaniom, przed jakimi stoi współczesna Europa. Do najważniejszych z nich zaliczyć można konieczność podjęcia działań w zakresie przeciwdziałania peryferyzacji gospodarki europejskiej na arenie globalnej oraz skutkom niżu demograficznego i starzenia się społeczeństwa. W ramach procesu bolońskiego w celu stworzenia konkurencyjnej w skali globalnej gospodarki opartej na wiedzy podejmowane są działania w zakresie: usuwania barier dla mobilności naukowców i studentów, ujednolicanie systemów kształcenia poprzez ERK i KRK. W ramach strategii „radzenia sobie” z niekorzystną sytuacją demograficzną propaguje się reorientację uniwersytetów na kształcenie nowego typu studentów - osób dorosłych, aktywnych zawodowo. Najnowsze zmiany prawne wprowadzają również konieczność potwierdzania tzw. efektów uczenia się, zdobytych w miejscu pracy, poza formalną edukacją (por. ustawa z dnia 11 lipca 2014 r. o zmianie ustawy - Prawo o szkolnictwie wyższym oraz niektórych innych ustaw), co ma w jeszcze większym stopniu przyczynić się do realizacji idei kształcenia przez całe życie.

Również w kontekście polskim szczególne znaczenie dla przyszłego kształtu szkolnictwa wyższego będą miały zmiany demograficzne. Zjawisko umasowienia edukacji na poziomie wyższym dokonało się w czasie transformacji całego systemu społecznego oraz korzystnych dla rozwoju systemu szkolnictwa wyższego warunków demograficznych. W szkolnictwie wyższym upatrywano szansy na awans społeczny, poprawę sytuacji materialnej itp. Wysokie były również aspiracje edukacyjne młodych ludzi w tym czasie (CBOS 2009). Zainteresowanie kształceniem doprowadziło do rozrostu systemu szkolnictwa (w szczególności sektora prywatnego), co rodzi pewne konsekwencje w sytuacji, gdy z przyczyn demograficznych liczba studentów systematycznie maleje. W roku 1990 wynosiła ona w Polsce 400 tys., w roku 2005, kiedy pokolenie wyżu demograficznego wkroczyło w wiek typowy dla studiowania (19-24 lata), osiągnęła najwyższą wartość - 1954 tys. Od tego czasu liczba studentów stopniowa spada i w 2012 roku wynosiła już 1764 tys. Według prognoz w roku 2025 wyniesie około 1254 tys. (Ministerstwo Nauki i Szkolnictwa Wyższego 2013). Sytuacja ta będzie wymuszać zmiany, które aktualnie trudno przewidzieć, gdyż obecnie trwają negocjacje na temat zmian finansowania działalności uczelni w celu ich uniezależnienia od liczby studentów, co ma uchronić je przed negatywnymi skutkami zmian demograficznych, w tym spadku jakości kształcenia. W toczącej się debacie jako argument na rzecz uniezależnienia finansowania od tzw. współczynnika studencko-doktoranckiego podkreśla się pozostałe funkcje uczelni, związane z realizacją badań i tzw. trzecią funkcją, w postaci oddziaływania na otoczenie społeczne. Stanowią one uzasadnienie dalszego finansowania działalności z budżetu państwa uczelni majach problem z kandydatami na studia (Muszewska, Niesiołowski-Spano, Pieniądz 2015; por. http:// komitethumanistyki.pl /program/ postulaty-antykryzysowe/ [27.06.2015]).

Obecnie skutkiem tego dla wewnętrznego systemu szkolnictwa wyższego jest koncentracja zasobów w najsilniejszych ośrodkach, które wygrywają w toczącej się rywalizacji o najlepszych kandydatów na studia. Ponadto obniżenie w algorytmie finansowania wielkości tzw. współczynnika przeniesienia do poziomu 0,65 spowoduje, że coraz trudniej będzie słabszym ośrodkom rozwijać się, co w perspektywie przyczyni się do coraz silniejszej polaryzacji między ośrodkami najsilniejszymi w skali kraju i tymi słabszymi.

Kolejnym istotnym czynnikiem wpływającym na kształt szkolnictwa wyższego w Polsce jest jej półperyferyjny status w stosunku do europejskiego i światowego rdzenia rozwoju (Zarycki 2009). Zgodnie z modelem rozwoju zależnego (czy też zależności centro-peryferyjnych) Wallersteina można prognozować, że integracja europejskich systemów szkolnictwa 
wyższego doprowadzi do koncentracji zasobów (ludzkich, kulturowych) w najsilniejszych ośrodkach, a sytuacja obszarów słabszych prawdopodobnie ulegnie dalszemu pogorszeniu (Wallerstein 1976). Przyczyną pogłębienia peryferyzacji polskich uniwersytetów w skali europejskiej i globalnej może być niekorzystna sytuacja demograficzna nie tylko państw UE, ale również pozostałych, zrzeszonych w OECD. Według tezy zawartej w ostatniej diagnozie stanu szkolnictwa wyższego w Polsce, zrealizowanej przez KRASP, palącym problemem będzie odpływ najlepszych studentów i doktorantów do państw wysoko rozwiniętych, gdyż oferują one zachęty w postaci korzystniejszych warunków zatrudnienia i rozwoju, w przeciwieństwie do wąskich możliwości zatrudniania osób uzyskujących doktoraty w Polsce, co jest spowodowane spadkiem liczby studentów i ograniczonymi środkami przeznaczanymi na badania naukowe (Górniak 2015). Analiza mobilności studentów i naukowców w ramach programów wspierających umiędzynarodowienie polskiego systemu szkolnictwa typu Erasmus wskazuje na jej jednokierunkowość. Polska jest trzecim w Europie krajem najczęściej korzystającym z tego typu wyjazdów (najczęściej wyjeżdżamy do Stanów Zjednoczonych, Wielkiej Brytanii i Francji). Niski jest w Polsce wskaźnik mobilności przychodzącej zarówno studentów, jak i wykładowców. Odsetek studentów zagranicznych w stosunku do ogółu studiujących na terenie Polski jest jednym z najniższych w Europie. Do Polski w zdecydowanej większości na studia przyjeżdżają kandydaci z Białorusi i Ukrainy (Główny Urząd Statystyczny 2014). Wyzwaniem, zdaniem autorów raportu, jest „stworzenie możliwości kontaktu polskich studentów z zagranicznymi wykładowcami i uczelniami bez ułatwiania, czy wręcz stymulowania, trwałej emigracji osób najzdolniejszych" (Górniak 2015: 236). Diagnozy tego typu wskazują na rosnącą świadomość ryzyka pogłębienia się peryferyjności polskich uniwersytetów w sytuacji rosnącej mobilności. Pochodzenie studentów zagranicznych studiujących w Polsce wskazuje na praktykowanie w Polsce strategii charakterystycznych dla krajów półperyferyjnych, opisanych w modelu Wallersteina. Polegają one na stosowaniu przez półperyferie analogicznych mechanizmów osłabiania, jakie praktykują centra wobec peryferii, wobec regionów jeszcze bardziej oddalonych od światowego rdzenia. Na upowszechnianie się tego typu strategii w obszarze szkolnictwa wyższego wskazują statystyki dotyczące krajów pochodzenia studentów lubelskich uczelni. Znajdują się one w jednym z najbardziej oddalonych od europejskiego rdzenia obszarów zarówno w sensie terytorialnym, jak i ekonomicznym i jednocześnie posiadają najwyższy wskaźnik umiędzynarodowienia szkolnictwa wyższego w Polsce. Od 2001 roku niemal siedmiokrotnie wzrosła liczba studentów zagranicznych na Lubelszczyźnie, z czego niemal 60\% to studenci z Ukrainy. Najszybszy wzrost nastąpił po roku 2005, kiedy uczelnie zaczęły odczuwać skutki niżu demograficznego. W roku 2014 w Lublinie studiowało już 3979 studentów zagranicznych, a w 2001 roku było ich 542 (Główny Urząd Statystyczny 2014). Otwarcie uczelni na studentów ze Wschodu nie jest wyłącznie cechą województwa lubelskiego. Analizując wzrost wskaźnika umiędzynarodowienia ogółu polskich uczelni, można zauważyć znaczącą przewagą liczby studentów ze Europy Wschodniej oraz znacznie wyższą dynamikę wzrostu tej liczby w porównaniu z innymi państwami europejskimi. 


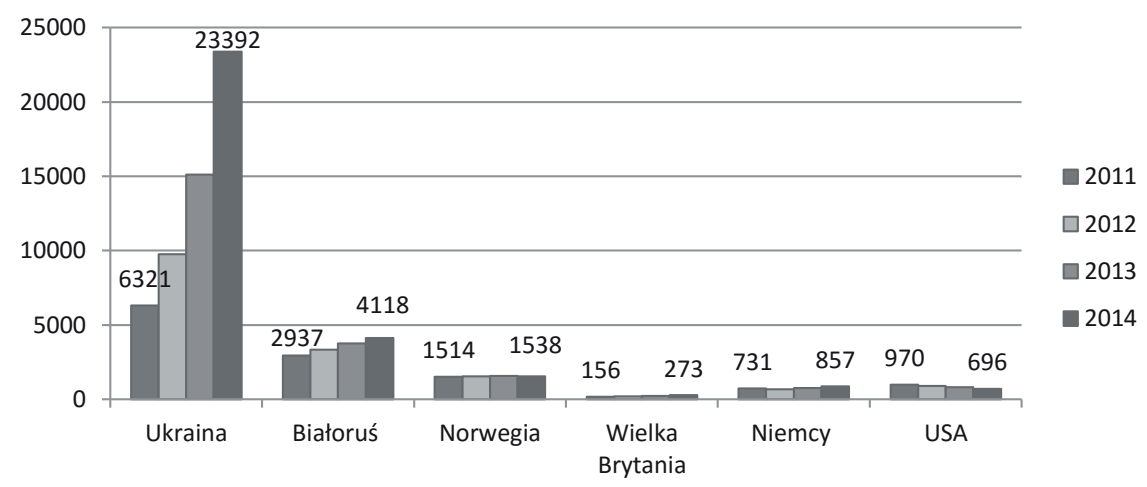

Rysunek 1. Studenci zagraniczni w Polsce w latach 2011-2014

Ujęcie Wallersteina pozwala zatem przewidywać, że w przyszłości wraz z postępowaniem integracji EOSW i EPB polskie uczelnie będą musiały rywalizować o najlepszych kandydatów na studia oraz pracowników naukowych z o wiele silniejszymi ośrodkami Europy Zachodniej, natomiast przeciwdziałając skutkom nierównej konkurencji, będą przyjmowały strategię charakterystyczną dla aktorów półperyferyjnych, polegającą na otwarciu się na Wschód, co w obecnej sytuacji geopolitycznej może być trudne i niepewne.

O rosnącej dominacji wiodących ośrodków akademickich na świecie pozwalają sądzić dane OECD na temat kierunków mobilności studentów. Wynika z nich, że kraje OECD niemal wyłącznie przyjmują studentów z zagranicy, o czym świadczy fakt, że trzy razy wyższa jest liczba studentów zagranicznych studiujących w tych krajach od liczby obywateli tych krajów wyjeżdżających na studia za granicę (OECD 2014). Ponad 50\% ogółu studiujących poza granicami swojego kraju jako cel wyjazdu wybrało jedno z sześciu państw: Stany Zjednoczone (16\% ogółu), Wielką Brytanię (13\%), Francję (6\%), Niemcy (6\%), Australię (6\%) lub Kanadę (6\%). Wśród krajów, do których wyjeżdżają polscy studenci, dominują rozwinięte kraje Europy Zachodniej, jak: Wielka Brytania (37,3\% ogółu studiujących za granicą), Niemcy (21,5\%), Francja (5,5\%), Irlandia (3,7\%), a spoza Europy - Stany Zjednoczone (3,7\%) (OECD 2014).

Zdaniem Kwieka peryferyjność polskiego systemu szkolnictwa wyższego wyraża się również w jego ograniczonym wpływie na kształtowanie modelu i kierunków rozwoju przez polskie środowisko akademickie i polityczne. Zdaniem tego autora „polskie uczestnictwo w pierwotnym formułowaniu i przeformułowaniu strategii lizbońskiej było niemal zerowe lub marginalne, podobnie jak nasze wpływy na kształt procesu bolońskiego" (Kwiek 2010b). Realizowane w Polsce zmiany mają charakter w znacznej mierze implementacji zachodnich rozwiązań do polskich warunków. Mają charakter modernizacji poprzez naśladowanie wzorców wypracowanych gdzie indziej.

Podsumowując, należy podkreślić, że polskie uniwersytety muszą się zaadaptować do nowych warunków, które najprościej można scharakteryzować jako proces powstawania nowych obszarów dominacji i podporządkowania. W kontekście międzynarodowym - wraz z postępującym procesem integracji europejskiej i globalizacji - z przyczyn demograficznych może dojść do pogłębienia peryferyjności polskich uniwersytetów na rzecz wzmocnienia najsilniejszych ośrodków zachodnich. Również na poziomie krajowym postępować będzie dominacja ośrodków najsilniejszych i pogłębiająca się peryferyjność ośrodków 
słabszych. Zmiany będą zachodzić również wewnątrz pola akademickiego. W konsekwencji podporządkowania działalności uczelni celom politycznym i gospodarczym zmienić się może jego wewnętrzna struktura. W sensie ekonomicznym i symbolicznym prawdopodobnie rosnąć będzie status przedstawicieli obszarów badań uznanych za wiodące, natomiast osłabianiu ulegnie prestiż przedstawicieli nauk o niższym potencjale komercyjnym. Z tego samego powodu wydaje się, że istnieje ryzyko marginalizacji znaczenia badań podstawowych na rzecz badań praktycznych oraz kształcenia holistycznego na rzecz kształcenia zawodowego - na potrzeby rynku pracy. W obliczu silnego dyskursu neoliberalnego i kryzysu państwa opiekuńczego coraz trudniej będzie uzasadniać konieczność finansowania z budżetu dyscyplin naukowych, których efekt rozwojowy jest trudno mierzalny i długoterminowy, co spowoduje osłabienie pozycji tych nauk. Ponadto polskie uniwersytety muszą obecnie konkurować nie tylko między sobą i z ośrodkami zagranicznymi, ale również z podmiotami zajmującymi się badaniami i kształceniem, a niemającymi statusu uczelni.

Obecnie w Polsce podejmowane są coraz częściej inicjatywy, które można interpretować jako próby przeciwstawienia się wskazanym tendencjom przez środowisko akademickie. Postulaty odnoszą się krytycznie przede wszystkim do wprowadzanego modelu zarządzania, finansowania oraz ogólnie rozumianego neoliberalnego uwikłania uniwersytetów (por. postulaty ruchów: KKHP, ON, Uniwersytet Zaangażowany, Uniwersytet Solidarny). Funkcjonujący w Polsce model uniwersytetu, choć finansowo uzależniony w znacznym stopniu od państwa, charakteryzuje się dużą autonomią, w związku z czym nie wszystkie próby redefiniowania tradycyjnej roli uniwersytetu mogą się powieść, a na pewno - w przekonaniu autora - należy spodziewać się rosnącego oporu głównego podmiotu, którego zmiany dotyczą.

\section{Zmiana modelu funkcjonowania uniwersytetu}

Istnieje wiele modeli zarządzania w szeroko rozumianym sektorze szkolnictwa wyższego. Agnieszka Olechnicka w przeprowadzonej analizie strategii modeli działania oraz ścieżek ewolucji wiodących szkół wyższych na świecie powołuje się na wieloczynnikowy model Clarka, najczéściej przywoływany w literaturze przedmiotu punkt odniesienia w analizie funkcjonowania uczelni (Olechnicka 2010). Model ten koncentruje się na roli trzech głównych aktorów zbiorowych w zakresie kształtowania ich funkcjonowania - państwa, rynku i oligarchii akademickiej. Na jego podstawie można wyróżnić trzy modele funkcjonowania uczelni wyższych: model biurokratyczny, rynkowy oraz model oligarchii akademickiej. Granice pomiędzy nimi są trudne do jednoznacznego określenia, gdyż często różnica dotyczy proporcji określonych cech posiadanych przez wszystkie uniwersytety, niemniej pozwalają one wyodrębnić pewne modele do celów analitycznych. Pierwszy z nich, model biurokratyczny, charakteryzuje się dużym wpływem państwa i jednocześnie ograniczonym wpływem rynku i środowiska akademickiego na kształt systemu szkolnictwa wyższego. W modelu rynkowym natomiast zarówno rola państwa, jak i środowiska akademickiego jest ograniczona, a działalność uczelni podporządkowana w zdecydowanym stopniu logice rynkowej. Ostatni z wyróżnionych, model oligarchii akademickiej, charakteryzuje się największym stopniem podmiotowości środowiska akademickiego i jego wpływu na kształt systemu szkolnictwa wyższego. Państwo i rynek mają tu znaczenie niewielkie. Model ten, najbardziej zbliżony do humboldtowskiego modelu uniwersyteckiego, charakteryzuje szeroka autonomia w zakresie programów nauczania, struktur organizacyjnych oraz alokacji środków, które pochodzą przede wszystkim ze źródeł publicznych (Clark 1983; Olechnicka 
2010). W Polsce mamy do czynienia z funkcjonującymi równolegle dwoma modelami zarządzania uczelniami. W sektorze prywatnym dominuje model rynkowy, natomiast w publicznym w większym stopniu występuje model oligarchii profesorskiej (Theime 2009).

Badania nad zmianą funkcji uniwersytetów wskazują, że w coraz większym stopniu w krajach wysoko rozwiniętych gospodarczo zmiany w szkolnictwie wyższym zmierzają w kierunku rynkowego modelu zarządzania, zwanego również modelem managerskim (Olechnicka 2010). Coraz większy nacisk kładzie się na implementację instrumentów maksymalizowania wydajności, charakterystycznych dla sektora przedsiębiorstw prywatnych. Większość krajów zrzeszonych w OECD od ponad trzech dekad wprowadza zmiany w dziedzinie zarządzania uczelniami, które najczęściej bywają określane jako tzw. Nowe Zarządzanie Publiczne (New Public Management), realizujące model zarządzania w sektorze publicznym analogiczny do modelu sprawdzonego w sektorze przedsiębiorstw prywatnych. W modelu tym, ujmując rzecz najogólniej, wzrost efektywności i wydajności danej organizacji osiągany jest poprzez rywalizację - o zasoby, renomę i pozycję w rankingach (Whitley, Gläser 2014). Jednym z głównych czynników wpływających na decyzję o implementacji tego modelu do sektora instytucji publicznych jest ich kluczowa rola w generowaniu innowacji, a także kurczące się środki finansowe, które państwa narodowe są w stanie przeznaczać na utrzymanie uniwersytetów i zapewnienie warunków dla rozwoju wysokiej jakości badań oraz kształcenia. Obecnie jest to model upowszechniany również w Polsce, gdzie opierając się na rywalizacji, rozdysponowuje się środki na finansowanie uniwersytetów. Ponadto w nowym modelu promuje się koncepcję uniwersytetu przedsiębiorczego, zmierzającego do uniezależnienia się od środków publicznych.

\section{Strategie adaptacji polskich uniwersytetów do lokalnego i globalnego kontekstu}

Analizując sytuację polskiego systemu szkolnictwa wyższego, należy przyjąć perspektywę zorientowaną na badanie zmiany społecznej. W wyniku opisanych wcześniej tendencji globalnych, ale również uwarunkowań lokalnych, można wyróżnić dwie kategorie czynników determinujących proces zmian. Są to czynniki intencjonalne, związane z urzeczywistnianiem pewnej wizji, czy też projektu rozwoju, oraz czynniki obiektywne, niezależne od woli interesariuszy, takie jak demografia i dochody państwa. Obie te kategorie czynników składają się na środowisko funkcjonowania uniwersytetów, które staje się coraz bardziej skomplikowane i w rezultacie tej komplikacji wzrasta również złożoność samych uniwersytetów. Skuteczna adaptacja uwarunkowana jest odpowiednim reagowaniem na sygnały z zewnątrz. Wynikiem tej adaptacji jest widoczne w analizowanych przez autora dokumentach strategicznych przesunięcie od modelu oligarchii profesorskiej do modelu rynkowego. Zmiany tej nie można jednak interpretować jako zastąpienie jednego modelu drugim. Zdaniem E.P. Berman (2012: 265) zmiany instytucjonalne zazwyczaj mają tylko do pewnego stopnia charakter sterowalny, w dużym stopniu stanowią efekt lokalnych innowacji, polegających na testowaniu różnych rozwiązań problemów napotkanych przez aktorów społecznych. Pewne skuteczne rozwiązania zostają następnie zinstytucjonalizowane, natomiast inne nie są z różnych powodów przyjmowane. Najogólniej można te powody określić jako znaczące różnice w charakterze strukturalnym instytucji, będących utrwaIoną formą historycznego procesu ich adaptacji do środowiska. Proces zmiany zazwyczaj charakteryzuje ścieranie się nowych i starych rozwiązań, które prowadzi do ukształtowania się pewnego „hybrydalnego” modelu, łączącego elementy obu z nich. Dokonana przez autora analiza strategii rozwoju piętnastu polskich uniwersytetów (trzy z nich w momencie 
badania jeszcze nie udostępniły dokumentów strategicznych) wykazuje, że w strukturze celów i środków ich realizacji można zauważyć właśnie pewną wyłaniającą się hybrydalną formę ich funkcjonowania.

W zakresie zarządzania większość uniwersytetów zmierza w kierunku modelu rynkowego, opartego na zarządzaniu strategicznym (o czym może świadczyć już samo istnienie strategii będących przedmiotem analizy). Potrzeba doskonalenia mechanizmów zarządzania dostrzegana jest również przez środowisko akademickie, o czym świadczy przywołana już diagnoza szkolnictwa wyższego w Polsce, przygotowana przez Konferencję Rektorów Akademickich Szkół Polskich. Postuluje się w niej wprowadzenie na większą skalę managerskiego modelu zarządzania (opartego na obecnym systemie kanclerskim), jednak przy utrzymaniu nadrzędności władzy rektorskiej, w większym stopniu zakorzenionej w polskiej tradycji uniwersyteckiej.

Wspomniana dwoistość modelu działania widoczna jest również w zakresie rozwoju jednej z podstawowych funkcji uniwersytetu, jakim jest kształcenie. Uniwersytety wskazują jako cel realizację idei kształcenia uniwersyteckiego w jego klasycznym rozumieniu, przy jednoczesnym założeniu modyfikacji oferty w celu jej dostosowania do zmieniających się oczekiwań „interesariuszy” zewnętrznych i uwarunkowań demograficznych. W tym celu proponuje się uelastycznienie oferty zarówno w zakresie organizacji procesu kształcenia, jak i indywidualizacji jego programu. W coraz większym stopniu rozwijana jest oferta kształcenia komercyjnego, studiów podyplomowych, kursów, kształcenia ustawicznego, a także tzw. uniwersytetów trzeciego wieku. Wszystkie te elementy wynikają z adaptacji do niekorzystnej sytuacji finansowej i demograficznej. W strategiach widoczne są również cele będące efektem nakładanych w ramach reform obowiązków, takich jak rozwój mechanizmów ewaluacji jakości kształcenia, umiędzynarodowienie, m.in poprzez „przyciąganie” najlepszych studentów i naukowców z zagranicy, a także powiązanie kształcenia z oczekiwaniami ,interesariuszy zewnętrznych”.

W zakresie badań można również zauważyć mieszanie się tradycyjnych komponentów z nowymi, wynikającymi ze zmieniającego się kontekstu społecznego tworzenia wiedzy. Wskazuje się na dążenie do prawdy, jako głównej wartości, i realizację wysokiej jakości badań podstawowych, jednak znaczące miejsce mają praktyczne implikacje wiedzy oraz jej potencjał komercyjny. Celem strategicznym jest umiędzynarodowienie badań, dywersyfikacja źródeł ich finansowania oraz powiązanie ich z potrzebami otoczenia społeczno-gospodarczego. Zakłada się wprowadzanie mechanizmów stymulowania efektywności wykorzystywania zasobów kadrowych ich rozwoju, premiowanie aktywności w celu osiągnięcia wyższej pozycji uczelni w rankingach.

W ramach tzw. trzeciej misji, polegającej na oddziaływaniu uczelni na jej otoczenie gospodarcze, również zaznacza się wyraźna granica między misją tradycyjną i nową, związaną z procesem „marketyzacji” działalności uniwersytetu. W przypadku tej pierwszej podkreśla się rolę kulturotwórczą, opiniotwórczą i ekspercką w zakresie rozwoju regionu. W przypadku rynkowego charakteru zmian w zakresie powiązania działalności uczelni z jej otoczeniem wskazuje się na działania w kierunku kreowania jego pozytywnego wizerunku w otoczeniu, transferu wiedzy do gospodarki i stymulowania jej rozwoju poprzez dostarczanie innowacji. 


\section{Zakończenie}

Zmieniające się uwarunkowania funkcjonowania polskich uniwersytetów będą miały z pewnością niebagatelny wpływ na ich przyszły kształt. W obecnej sytuacji zarysowuje się model łączący w sobie elementy tradycyjne, odpowiadające humboldtowskiej tradycji, oraz nowe, związane z koniecznością dostosowania funkcjonowania uniwersytetów do reguł rynkowych. Dostosowanie to polega na stymulowaniu konkurencyjności, doskonaleniu mechanizmów zarządzania oraz pomiaru jakości i wydajności w dziedzinie podstawowych procesów i efektów działalności uczelni. Kreowane zmiany w zakresie zarządzania uniwersytetem muszą jednak uwzględniać specyfikę tej instytucji, jej tradycje, wewnętrzną logikę oraz kontekst kulturowy. Wynikające z tych czynników różnice wpływają znacząco na zdolność tej instytucji do przyswojenia narzuconego modelu. Decyzje polityczne w zakresie wdrażania New Public Management w sektorze szkolnictwa wyższego wydają się ignorować fakt, jakim jest specyfika pola społecznego nauki, rządzącego się odmienną logiką niż pole gospodarki. Mówiąc językiem Bourdieu, inne są tu stawki i reguły gry napędzające wewnętrzną dynamikę pola niż ma to miejsce w przedsiębiorstwie. Mechanizm konkurencji jest tu silnie obecny, jednak konkurencja dotyczy kapitału kulturowego, a nie ekonomicznego. W polu naukowym uznanie zyskuje się poprzez rzetelność badań, rygor metodologiczny, istotny wkład do nauki i wiedzy, stanowiącej wartość autoteliczną. Drugorzędne znaczenie ma potencjał komercyjny wiedzy. Przyjęcie sposobu oceny dorobku naukowego w kategoriach efektywności, mierzonej ilościowymi wskaźnikami, zasadniczo ingeruje w logikę pola naukowego, będącego gwarantem jakości i rozwoju badań podstawowych. Tego typu stymulacja wydajności pracy naukowców jest powszechnie krytykowana, ponieważ wiąże się z ryzykiem spłycenia analiz naukowych oraz ich powierzchowności, wynikających z konieczności szybkiego publikowania możliwie największej liczby opracowań.

Również w zakresie doskonalenia procesu kształcenia wskazuje się na ograniczoną skuteczność stosowanych narzędzi. W obecnym kształcie przyjmują one postać mechanizmów kontroli jakości procesu oraz produktu, charakterystycznych dla przedsiębiorstw. Wskazywana w raporcie KRASP ograniczona skuteczność stosowanych mechanizmów ewaluacji (Górniak 2015) w przekonaniu autora wynika z faktu, że nie są one dostosowane do specyfiki instytucji, jaką jest uniwersytet. Pomimo że formalne procedury ewaluacji zostały wdrożone we wszystkich uczelniach, nie zawsze spełniają one swoją funkcję. W przekonaniu autora ich skuteczność wymaga przeformułowania głównego celu takich badań z kontroli jakości na uczenie się, poszukiwanie uwarunkowań skuteczności procesu kształcenia, a w relacji z otoczeniem - na pogłębienie analiz długookresowych trendów, a nie koncentracji na chwilowych potrzebach pracodawców. Nie jest to jednak możliwe przy zastosowaniu wyłącznie ilościowych wskaźników efektywności kształcenia, gdyż pogłębienie analiz wymaga dodatkowych nakładów, niemniej potrzebna jest socjologiczna refleksja na temat uwarunkowań skuteczności stosowanych mechanizmów. W obliczu permanentnej adaptacji do zmieniającego się otoczenia, w szczególności biorąc pod uwagę strategiczne otwarcie na potrzeby otoczenia, wydaje się potrzebne stworzenie skutecznych mechanizmów komunikacji z nim. Ograniczona skuteczność istniejących mechanizmów, w postaci badań opinii absolwentów, pracodawców itp., wynika ze specyfiki struktury uniwersytetów. Jak wcześniej wskazano, obok powstającego nowego modelu zarządzania w Polsce dominuje nadal tzw. model oligarchii profesorskiej, charakteryzujący się autonomią oraz silnie zhierarchizowaną strukturą, która stanowi barierę w realizacji modelu organizacji uczącej 
się (Olejniczak 2012). I choć realizowane badania często mają dużą wartość poznawczą, ich wyniki nie zawsze przekuwają się na działania.

Dyskurs naukowy i społeczny na temat współczesnej roli uniwersytetu w dużym stopniu świadczy o tym, że zmiany w nim zachodzące nie zawsze zmierzają w kierunku zgodnym z wewnętrzną i zakorzenioną kulturowo interpretacją jego tożsamości oraz funkcji. Analiza debaty toczącej się wokół tych przemian w Polsce dostarcza wniosków, że jego celem jest - rozumiane zgodnie z koncepcją Luhmanna - utrzymanie tradycyjnej tożsamości uniwersytetu i tym samym wskazanie zasadniczych różnic, jakie występują między wewnętrzną logiką i regułami rządzącymi jego funkcjonowaniem a logiką funkcjonowania innych systemów w społeczeństwie, w szczególności podmiotów gospodarczych. Świadczą o tym liczne inicjatywy, które wprost nawiązują do konieczności redefinicji lub reaktywacji idei uniwersytetu oraz wyraźnego wyznaczenia granicy między uniwersytetem a firmą komercyjną (do tych inicjatyw można zaliczyć: organizację Kongresu Kultury Akademickiej w 2014 roku pod hasłem: „Idea uniwersytetu - reaktywacja”; protest studentów UW pod hasłem: „Uniwersytet to nie przedsiębiorstwo"; działania Komitetu Kryzysowego Humanistyki Polskiej oraz ruchu Obywatele Nauki; działalność ruchów studenckich, takich jak: Uniwersytet Zaangażowany oraz Uniwersytet Solidarny; debatę zorganizowaną przez MNiSW 24 czerwca 2015 roku pod tytułem: „Jakie mają być nasze uczelnie i polska nauka?”).

Zagrożenia wynikające ze zmiany kontekstu funkcjonowania uniwersytetu trafnie diagnozuje Michael Burawoy (2013), wskazujący na dwa czynniki, które obecnie najsilniej strukturyzują pole nauki. Są to: nadmierna regulacja i utowarowienie. Autor ten pisze:

Poddawani jesteśmy dziś przymusowi instrumentalizacji, przekształcającej uniwersytet w narzędzie realizacji celów określanych poza światem akademickim i przybierającej formę utowarowienia oraz regulacji. Autonomia sprowadza się teraz do wyboru narzędzi do walki z deficytem budżetowym: restrukturyzacji wydziałów, zatrudniania pracowników dydaktycznych na czas określony, outsourcingu pracy usługowej, podnoszenia opłat za studia, inwestycji w kształcenie na odległość itp. (Burawoy 2013: 14).

W obliczu przemian, z jakimi mamy do czynienia, trudne do realizacji wydają się cele określane w dokumentach strategicznych polskich uniwersytetów. Kształtujące się nowe obszary dominacji i podporządkowania wskazują w szczególności, że strategie wzmocnienia polskich ośrodków poprzez ich umiędzynarodowienie, polegające na zachęcaniu najlepszych studentów i wykładowców z zagranicy do przyjazdu do Polski, będą trudne do realizacji. Bardziej prawdopodobna jest tendencja odwrotna, polegająca na „wysysaniu” najlepszych studentów i doktorantów przez ośrodki zachodnie. W konsekwencji należy się spodziewać mobilności jednostronnej - z ośrodków słabszych do silniejszych, zarówno na poziomie krajowym, jak i międzynarodowym.

Wspomniane podporządkowanie działalności uczelni gospodarce może doprowadzić do zaniedbania obszarów badań o niskim potencjale komercyjnym, których efekty nie poddają się szybkiemu utowarowieniu, oraz badań podstawowych. Niedofinansowanie humanistyki oraz nauk społecznych może spowodować spadek prestiżu i w konsekwencji spadek zainteresowania uprawianiem tych dyscyplin wśród kandydatów na studia, co w perspektywie może doprowadzić do trudności w zastąpieniu kadr w ośrodkach najbardziej peryferyjnych. Obniżenie statusu przedstawicieli tych dyscyplin w polu symbolicznym nauki może sprawić, że będą mieli oni mniejszy wpływ na jego kształtowanie, co pogłębi ich peryferyzację w polu. W związku z tym trudna do realizacji będzie również trzecia misja uniwersytetu, 
polegająca na jego kulturotwórczym oraz krytycznym zaangażowaniu na rzecz otoczenia społecznego. Oddziaływanie w coraz większym stopniu zawężać się będzie do stymulacji rozwoju gospodarczego poprzez dostarczanie nowych technologii.

\section{LITERATURA}

Bourdieu P., Wacquant L.J.D. 2006, Logika pól, w: Współczesne teorie socjologiczne, t. 2, red. A. Jasińska-Kania i in., Wydawnictwo Naukowe Scholar, Warszawa.

Bourdieu P., Wacquant L.J.D. 2007, Nowomowa neoliberalna, „Recykling Idei”, nr 9.

Burawoy M. 2013, Redefinicja publicznego uniwersytetu: ramy analityczne, „Praktyka Teoretyczna" nr 1 (7), http://www.praktykateoretyczna.pl/PT_nr7_2013_NOU/O2.Burawoy.pdf (29.04.2015).

Clark B.R. 1983, The Higher Education System: Academic Organization in Cross-national Perspective, University of California Press, Berkley.

Denek K. 2010, Sterowny czynnik rozwoju społeczeństwa wiedzy, w: Edukacja jutra. Edukacja w społeczeństwie wiedzy, red. K. Denek, Oficyna Wydawnicza Humanitas, Sosnowiec.

Diagnoza szkolnictwa wyższego. Program rozwoju szkolnictwa wyższego do 2020 r. 2014, red. J. Górniak, cz. III, FRP, KRASP, Warszawa.

Berman E.P. 2012, Explaning the Move Toward the Market in US Academic Science: How Instytutional Logics Can Change Without Instytutional Entrepreneurs, „Theory and Society”, May 2012, vol. 41, Issue 3.

Główny Urząd Statystyczny 2014, Dane wstępne dotyczące szkolnictwa wyższego, http://stat. gov.pl/obszary-tematyczne/edukacja/edukacja/dane-wstepne-dotyczace-szkolnictwa-wyzszego-2014-r-,8,2.html (25.06.2015).

Hatch M.J. 2002, Teoria organizacji, Wydawnictwo Naukowe PWN, Warszawa.

Kennedy M.D. 2014, Globalizing Knowledge. Intellectuals, Universities and Publics in Transformation, Stanford University Press, California.

Kraśniewski A. 2007, Proces Boloński - idea, dokumenty, realizacja, w: Jakość kształcenia w szkołach wyższych, red. T. Szulc, Oficyna Wydawnicza Biblioteki Warszawskiej, Wrocław.

Kwiek M. 2010a, Transformacje uniwersytetu. Zmiany instytucjonalne i ewolucja polityki edukacyjnej w Europie, Wydawnictwo UAM, Poznań.

Kwiek M. 2010b, Integracja europejska a europejska integracja szkolnictwa wyższego, CPP RPS, vol. 17, http://www.cpp.amu.edu.pl/pdf/CPP_RPS_vol.17_Kwiek.pdf (20.06.2015).

Luhmann N. 2008, Systemy społeczne. Zarys ogólnej teorii, Wydawnictwo Nomos, Kraków.

Ministerstwo Nauki i Szkolnictwa Wyższego 2013, Szkolnictwo wyższe w Polsce, Warszawa.

Muszewska A., Niesiołowski-Spano Ł., Pieniądz A. 2015, Pakt dla nauki, czyli jak nauka może służyć społeczeństwu, Warszawa, http:// obywatelenauki.pl wp-content/uploads/2015/05/ Pakt_dla_Nauki.pdf (26.06.2015).

OECD 2014, Education at a Glance 2014: OECD Indicators, OECD Publishing, http://www.oecd. org/edu/Education-at-a-Glance-2014.pdf (26.06.2015).

OECD 2015, OECD Skills Outlook 2015: Youth, Skills and Employability, OECD Publishing, http:// dx.doi.org/10.1787/9789264234178-en. 
Olechnicka A. i in. 2010, Analiza strategii, modeli działania oraz ścieżek ewolucji wiodących szkół wyższych na świecie. Raport z badania, Politechnika Warszawska, Warszawa.

Olejniczak K., Rok J. 2012, Determinanty uczenia się i zarządzania wiedzą - synteza badań empirycznych, w: Organizacje uczące się. Model dla administracji publicznej, red. K. Olejniczak, Wydawnictwo Naukowe Scholar, Warszawa.

Theime J.K. 2009, Szkolnictwo wyższe. Wyzwania XXI wieku. Polska, Europa, USA, Difin, Warszawa.

Ustawa z dnia 11 lipca 2014 r. o zmianie ustawy - Prawo o szkolnictwie wyższym oraz niektórych innych ustaw, Dz.U. 2014, poz. 1198.

Wallerstein I. 1976, The Modern World-System. Capitalist Agriculture and the Origins of the European World-Economy in the Sixteenth Century, Academic Press, New York-San Francisco-London.

Wciórka B. 2009, Aspiracje i motywacje edukacyjne Polaków w latach 1993-2009. Komunikat z badań CBOS. BS/70/2009, Warszawa.

Whitley R., Gläser J. 2014, The Impact of Instytutional Reforms on the Nature of University as Organization, ,,Research in the Sociology of Organization”, vol. 42.

Zarycki T. 2009, Peryferie. Nowe ujęcie zależności centro-peryferyjnych, Wydawnictwo Naukowe Scholar, Warszawa.

Zarycki T. 2014, Innowacjonizm jako legitymizacja, „Zarządzanie Publiczne”, nr 1 (27).

\section{STRONY INTERNETOWE:}

http://obywatelenauki.pl

http://komitethumanistyki.pl/

\section{POLISH UNIVERSITIES ADAPTATION STRATEGIES TO CONTEMPORARY SOCIAL REALITY}

SUMMARY In article the author tries to present trends in terms of changing the management model in higher education. Based on the analysis of polish universities strategic documents, as well as on the basis of literature on the subject, the author attempts to describe the process of change taking place in this area. Author used a processual approach in analyzing of organization, based largely on Niklas Luhmann's theory of social systems. From this perspective, universities development strategies are interpreted as a form of adaptation to changing political, socio-economic and demographic context. The author also used Pierre Bourdieu's theory of social fields in order to describe the emerging complex relationships of domination and subordination, as a consequence of changes in the context of the functioning of Polish universities. In order to expose the center-periphery relations that are taking place in the emerging new field of higher education author used Immanuel Wallerstein's world-system theory.

\author{
KEYWORDS \\ CHANGES WITHIN \\ THE FIELD OF HIGHER \\ EDUCATION, SOCIOLOGY OF \\ ORGANIZATIONS, ANALYSIS \\ OF THE SOCIAL FIELDS, \\ RELATIONS OF DOMINATION \\ IN THE ACADEMIC FIELD
}


